\title{
Islet of Langerhans
}

National Cancer Institute

\section{Source}

National Cancer Institute. Islet of Langerhans. NCI Thesaurus. Code C12608.

The pancreatic tissue that contains the islets of Langerhans. It is responsible for the production and secretions of the pancreatic hormones. 